\title{
Federal Trust Funds: An Idea Whose Time is Over
}

\author{
Tim Rosadot
}

Tim Rosado is in his final semester of the master of public administration program. His concentration is budgeting and public finance. Mr. Rosado graduated from the State University of New York at Brockport with a bachelor of science in business administration.

The persistent struggle to address the federal budget deficit and other serious budget problems has brought to the fore the need to undertake comprehensive budgetary reforms. Little attention has been paid, however, to one aspect of federal budgeting which should be considered within any reform effort - trust fund budgeting.

The ability of Congress to addiress fecleral budget problems is made more difficult because of the existence of fecleral trust funds. Trust funds restrict Congress by facilitating the automatic compartmentalization of a large amount of fecleral resources into just a few programs. The effect of trust funds on the process of budgeting is to limit the flexibility and control that is critical to appropriately allocating limited federal resources.

The federal government should move away from trust fund budgeting to foster a more effective and responsive budgetary regime. Changes in trust fund budgeting will provide Congress and the Presictent the ability to more easily construct budgets for the nation which are deliberate and fair in the distribution of funds to competing programs, and to a larger degree, whole generations.

This article will outline the case for reducing the influence of trust funds on the federal budget. Specific problems arising from trust fund use will be described in relation to current budgetary processes. Options which address trust fund problems will then follow.

\section{What Are Federal Trust Funds?}

The meaning of trust funds is a source of some confusion. In the simplest sense, trust funds are an accounting device used in budgeting. The federal budget contains two types of funds: federal funds and trust funds. Federal funds represent spending from the so-called "general fund" portion of the budget, which contains revenue not designated for any specific purpose and for "special" and "revolving" funds. ${ }^{1}$ Trust funds, on the other hand, are budgetary accounts which are credited by the Treasury with dedicated tax revenues and transfers from the general fund portion of the budget. By law, credited amounts within the trust funds are invested in Treasury securities. ${ }^{2}$

Past decisions of Congress to designate budget accounts as either a trust fund or a federal fund account have not been based on any systematic rule. ${ }^{3}$ Typically, trust funds have been designated as such for long-term purposes. ${ }^{4}$ Some have been established with the understanding that if the public pays certain taxes, the federal government would finance some specified activity. Others do not require a specific tax, but still represent a commitment to undertake a specific activity. A third type is a combination of the two where funding for an activity comes partly from taxpayers and partly from the government.,

In total, there are more than 150 trust funds. ${ }^{6}$ Table 1 provides a list of the major trust funds, or trust fund categories, along with their balances. The largest trust funds, by far, are the Social Security Trust Fund and the civil service retirement trust funds for federal employees. These trust funds, along with the military retirement and Medicare Part A trust funds, constitute almost 87 percent of total trust fund balances. ${ }^{7}$

In fiscal year (FY) 1995, 41 percent of federal receipts from taxes and other sources were dedicated to federal trust funds. More than 43 percent of all federal outlays were financed from them. The cumulative balance of all trust funds exceeded a staggering $\$ 1.28$ trillion. 


\section{Table 1 TRUST FUND BALANCES OF SELECT TRUST FUNDS \\ (dollars, in billions)}

\begin{tabular}{lrr} 
Inust Fund & 1995 & 2002 \\
Social Security (OASDI) & 483.2 & $1,075.8$ \\
Federal Employee Retirement & 374.3 & 579.0 \\
Medicare Part A & 129.5 & 128.0 \\
Military Retirement & 126.7 & 147.3 \\
Unemployment & 47.9 & 96.1 \\
Highway & 19.0 & 60.4 \\
Roilroad Retirement & 14.4 & 19.1 \\
Medicare Part B & 13.9 & 36.9 \\
Veterans Life Insurance & 13.6 & 13.8 \\
Airport and Airway & 11.4 & 17.0 \\
Federal Employee Health & 7.8 & 10.4 \\
Foreign Military Sales & 5.5 & 5.3 \\
Other & 35.2 & 57.3 \\
\hline TOTAL & $1,282.4$ & $2,246.4$ \\
\hline
\end{tabular}

* Projected under President Clinton's FY 1997 budget request.

Source of figures: OMB, FY 1997 Budget Request of the President, Analytical Perspectives.

\section{The Origin of Trust Fund Budgeting}

Trust funds are much more than an accounting device. A review of the origin of federal trust funds provides insight into their nature and meaning. The first trust fund established by the federal government was the Civil Service Retirement and Disability Fund under the Civil Service Retirement Act of 1920 (P.L. 66-215). Congressional debate on the original legislation suggests that the purpose of establishing the federal pension system, and consequently the trust fund, was to emulate features of the private pension system. As Representative Adolphus Nelson (R-WI) stated during the bill's consideration in the House:

It is quite evident to anyone who has studied the business of our government that we need to introduce into our various governmental departments more business efficiency...[the bill] is based upon the best scientific research made of the various pension plans or retirement plans now in force in this and other countries of the world. ${ }^{g}$

The enacting statute required that a portion of this trust fund be invested "from time to time" in interest-bearing securities of the United States. ${ }^{9}$ In this first federal trust fund, precedent was established for the current investment method of all trust fund receipts.

Additional trust funds were not created until 1935, when the Social Security Act of 1935 (P.L. 74-271) established the unemployment compensation, or "insurance,". program in tandem with the old-age survivor's insurance program, commonly known as Social Security. For unemployment insurance, a trust fund was set up where state-collected employer contributions were deposited into the federal treasury for "investment" by the Treasury in "outstanding obligations" of the United States or "special non-negotiable" securities, with the Treasury acting as a "banker" and "trustee" of the funds. ${ }^{10}$ Once again, the purpose of establishing this trust fund appears to have been an attempt to imitate the workings of private financial systems, in this case, the private insurance system. ${ }^{11}$

Like the dedicated revenues for civil service retirement, unemployment compensation revenues were required to be invested in U.S. securities. The purpose for doing so was both economic and political: Congress was concerned that placing these dedicated funds in private securities could worsen an economic downturn and put the value of unemployment benefits at risk. As the initial House Report to the law explained:

[If] it is necessary to sell the securities in which the unemployment reserve funds are invested at any price they will bring, considerable losses are almost certain to be sustained and the net effect will be to increase the tendency towards deflation... The Iselling] on the market of such an amount... would offset any open-market operations of the Federal Reserve Board to maintain credit stability. ${ }^{\text {t2 }}$

In addition, the report described that investing funds in U.S. securities would enable sales of securities outside of the markets and would help "to maintain the purchasing power" of unemployed workers during economic downturns. $^{13}$

The largest trust fund currently in existence, the Social Security Trust Fund, was not established as a "trust fund" until four years after the enactment of the Social Security Act. Prior to the trust fund's creation, financial transactions 
of Social Security were handled through an "old-age reserve account" in the budget which received dedicated revenues which were invested in Treasury securities, the same as existing trust funds of the time. ${ }^{14}$ The Social Security Act Amendments of 1939 (P.L. 76-379) established the trust fund and explicitly designated the Secretary of the Treasury as "managing trustee" of the funds.

Congress' rationale for changing the designation of the oldage reserve account for Social Security to a "trust fund" is not clear. The origin of the decision has its roots in the recommendations of the 1937 Advisory Council on Social Security. The Council, made up of appointed employers, employees, and noted scholars, specifically asked that a trust fund be established in place of the old-age reserve account. As the Council stated:

It is believed by the council that such a procedure would enhance public understanding of the contributory insurance system. Since the tax proceeds thus credited are intended for payment of benefits, it is recommended that they be deposited in a trust fund under the control of designated trustees. ${ }^{16}$

The Council's recommendation went on to refer to this change simply as a "technical improvement" which would "simplify and strengthen the financial provisions of the program.."17

Congress referred to the financing structure under the 1939 amendments to the Social Security Act as being "safer" for workers, employers and the general public. ${ }^{18}$ Under alterations to the tax and benefit schedule enacted in the amendments, tax rates for Social Security were projected to increase from 1 percent on employees and employers to 3 percent by 1949 . The balance of the trust fund was projected to increase from $\$ 1.8$ to $\$ 7.7$ billion by $1955 .{ }^{19}$ This expansion, along with the desire to promote a perception in the public that funding for the program was protected, probably led Congress to change the label for the Social Security reserve account to a "trust fund."

By 1956, a number of other federal trust funds had been established which were of a similar nature to the Social Security, unemployment, and civil service trust funds. Other large programs with trust funds established for the benefit of individual beneficiaries included the Railroad Retirement Trust Fund and Veterans' Life Insurance Trust Fund.

However, in 1956 Congress passed the Federal Highway Aid Act (P.L. 84-627) establishing the Highway Trust Fund which departed from traditional trust fund patterns of the time. ${ }^{20}$ The Highway Act dedicated, or "earmarked," certain existing excise taxes to a Highway Trust Fund to be used for highway construction projects around the country.

A departure from tradition occurred because the earmarked revenue represented for the first time general revenues withheld from the budget and allocated to a general public purpose. Prior to the Highway Act, these tax revenues were collected and deposited into the general fund of the federal budget. Only targeted social programs with specific beneficiaries like Social Security had, until that time, been the beneficiaries of earmarking. ${ }^{21}$

Over time, therefore, the nature of federal trust funds had changed. Funds were established not just for contributory programs where contributions were registered in a government account for the payment of benefits to beneficiaries, but were also established to facilitate spending on programs with more general public purposes - such as highways. Other major trust funds established after the Highway Act to finance programs with general public purposes included the Airport and Airway Trust Fund and the Aquatic Resources Trust Fund. The Medicare Trust Fund, established in 1965 with beneficiary contributions, is similar to the pre-1956 trust fund genre.

Trust funds have also evolved with respect to their treatment within the budget. Prior to 1969 , trust funds were not counted in the regular or "administrative" budget. The administrative budget included only receipts and expenditures moving into and out of the general fund of the Treasury which were subject to the appropriations process. Trust funds were set apart from the administrative budget, except within limited economic analysis sections of the budget. $^{22}$

\section{Trust funds have also evolved with respect to their treatment witbin the budget.}

In 1967, President Johnson appointed a commission of experts, the Commission on Budget Concepts, to look at a broad variety of budget issues centering on budgetary accounting and presentation subjects. ${ }^{23}$ One of the issues the Commission reviewed was the appropriateness of the administrative budget and whether a unified budget, which combined both federal and trust fund accounts, would provide a more accurate picture of the budget for legislators, other policymakers, and the public.

To supporters of a budget which separated "administrative" and "trust fund" money, a divided approach appropriately 
reflected the fact that the responsibility of Congress to the rust funds is different from federal funds, making separate accounting for the two necessary. Supporters of a unified budget, on the other hand, saw that the omission of a large and important portion of federal receipts and spending inhibited flexibility and an accurate measurement of the costs of alternative policies, and that the administrative budget encouraged the perception that funding for many areas of government was being concealed. ${ }^{24}$

The Commission ultimately supported the unified budget approach. ${ }^{25}$ Specifically, the Commission held that the existence of several budgets led to confusion about the budget among the press, Congress, and other experts. A unified budget was essential for determining an appropriate economic policy and allocating funds for competing programs. $^{26}$

However, the Commission did not go so far as to support the elimination of separate trust fund accounting within the unified budget structure. The Commission held that, at least in theory, "trust funds do not belong to the federal government; the federal government acts only as a trustee for them. ${ }^{27}$ Accordingly, the Commission felt that a separate accounting of trust fund receipts and expenditures would help to protect the integrity of the trust funds and ensure budgetary control and accountability. Programmatic decisions, according to the Commission, were best made within the context of individual fund evaluation, not within the context of combined trust fund totals or totals of federallymowned funds excluding trust funds. ${ }^{28} \mathrm{~A}$ unified budget structure of this type was subsequently adopted in 1969 and still exists to this day.

An understanding of the development of trust fund budgeting over time is helpful in understanding trust fund problems discussed in the next section. Trust funds were developed for a variety of reasons, including those that are more practical, such as protecting funds from changes in economic conditions and facilitating the administration of employee pension funds. On the other hand, trust funds have also been established for political reasons, such as placating the public as large taxes were levied for specific purposes such as Social Security or to ensure that funding for long-term programs was made more resistant to shortterm budgetary processes.

The difficulty in addressing trust fund problems can be traced to the evolution of trust fund budgeting over the last seventy-five years. If, indeed, political reasons for trust fund budgeting are more compelling than practical reasons for using trust funds, then a significant change of course concerning their use may be unrealistic at the present time.
This principle especially holds true if the public considers Congress a trustee of these funds, not unlike a trustee in a private fiduciary situation.

\section{What's Wrong With Federal Trust Fund Budgeting?}

Budgets must attempt to reconcile the competing demands of today's taxpayers with those of tomorrow. Federal trust funds are useful in providing a budget mechanism by which to achieve a necessary balance in the allocation of federal resources between individual budget years and whole generations. ${ }^{29}$

\section{The difficulty in addressing trust fund problems can be traced to the evolution of trust fund budgeting over the last seventy-five years.}

But there are significant drawbacks to the use of trust funds. One is the problematic state of the trust funds in terms of their relative size to the total budget. The increased automatic compartmentalization of limited resources into certain programs leads to greater difficulty in exercising budget flexibility and control.

Relative size, however, is but one consideration. Underlying the trust fund problems are more complex issues affecting budget flexibility and control which undermine the ability of federal legislators to achieve an objective and rational balance of resource allocation as well as address difficult budget issues such as the federal budget deficit.

In describing the more complex considerations at hand, a conceptual framework will be utilized to examine trust fund problems. Trust funds problems derive from those that either are mostly "process" oriented or "political" in nature. Of course, federal government processes are inherently political, especially the budget process, and these issues naturally interrelate and overlap, often to a great extent. However, for the purpose of this analysis, political problems and process problems will be viewed separately to better illustrate the likelihood and limitations of any proposed change in budget policies to address trust fund problems.

\section{Political Problems}

Two political problems exist which relate to trust funds: 
the distorted "meaning" of a trust fund and the practice of earmarking. First, the simple use of the label "trust fund" on federal budgetary accounts has fostered a tendency to avoid addressing budget problems which have arisen partly because of programs funded from trust funds. A political problem exists because the public's perception about the meaning of trust funds has served a political purpose in protecting such programs from budget cuts. ${ }^{30}$ An examination of the meaning of a trust fund sheds light on this assertion.

A trust fund, in common usage, refers to money which belongs to one party held "in trust" by another operating as a fiduciary. ${ }^{31}$ The money within a trust must be used in accordance with the trust's terms, which the trustee cannot unilaterally modify, and is maintained separately from other trusts and the trustee's own funds. Fiduciary responsibility requires, at least in the case of pension plans, that the fiduciary act "prudently and solely in the interest of plan participants." ${ }^{32}$

Federal trust funds have an entirely different meaning. A fiduciary relationship generally does not exist between trust fund beneficiaries and the government. ${ }^{33}$ Beneficiaries do not own funds and the terms in those laws which created the trust fund can be unilaterally altered by Congress. In the simplest terms, federal trust funds are merely government funds administered separately from other funds and used for a specified purpose. ${ }^{34}$

The distinction between these two meanings is obviously important. If trust funds are perceived as a mere accounting device, legislators would have less difficulty from a political standpoint in drawing down trust fund accounts for alternative purposes.$^{35}$ Legislators would also have little incentive to create trust funds in the first place, since the value of trust funds is based on both the perception and reality that programs financed by such accounts are generally less vulnerable to the budget cycle.

Public perception of the meaning of trust funds includes the view that amounts in the trust funds are held for beneficiaries in trust and that the federal government should therefore act in a manner much like a trustee of a private trust fund. A review of the recent congressional debate over the status of the Medicare trust find disclose this essential truth. As Representative John English (R-PA) stated:

Medicare is part of a social compact we have with America's seniors. We in Congress serve as fiduciaries for this program, charged with the ultimate responsibility for its solvency. ${ }^{36}$

Representative Richard Gephardt (D-MO) has stated that "[t]here is more money coming into the [Medicare \& Social Security] trust funds than is spent, and we believe it is wrong to make up for problems somewhere else in the budget out of those trust funds. ${ }^{, 37}$

In response to this point of view, one could ask what is "wrong" with using funds from such trust funds for other purposes, if federal trust funds are just budgetary accounts. The answer is that using trust fund amounts for purposes other than providing benefits to beneficiaries is wrong because the public believes the federal government has a fiduciary responsibility to the ultimate beneficiaries of the trust fund accounts. This public understanding has limited the ability of Congress to bring trust fund program growth under adequate control.

A second political problem concerns the mechanism that trust funds collectively provide in helping the public exert a greater amount of control over the federal budget.

However, greater public control over the federal budget is not necessarily ideal from a "good budgeting" standpoint.

\section{Providing legislators a means of generating revenue for a specific purpose without having to raise general taxes makes earmarking attractive.}

Greater public control over federal spending occurs through "earmarking." Federal earmarking is the process of designating revenues to certain specific federal programs mostly trust fund programs. In 1994, the federal budget had 574 special and trust fund receipt accounts that received at least some earmarked receipts. Trust funds accounted for $\$ 520$ billion, or roughly 75 percent, of all earmarked receipts from the public. ${ }^{38}$

Providing legislators a means of generating revenue for a specific purpose without having to raise general taxes makes earmarking attractive. By linking revenue and outlays, earmarking ties the establishment of programs to agreement on their financing. ${ }^{39}$ This practice is a primary element of James Buchanan's popular public choice theory. ${ }^{40}$ Public choice theory attempts to explain, among other things, the tendency of public budgeting toward earmarking. Buchanan offers the example of the financing of Social Security in illustrating the earmarking aspect of public choice theory:

The public-choice paradigm draws direct attention to the bridge between the tax and spending side of the account... this bridge is influenced by perception, 
and even within the confines of payroll tax analysis, the effects of the structural features on voter-politician attitudes become important... payroll taxes are earmarked for the social security trust fund account. This fact, in itself, strongly suggests that these taxes are viewed differently from other general-fund revenue sources. ${ }^{41}$

To John Cogan, author of The Budget Puzzle, earmarking has led to a two-tiered tax bias which has contributed to the decline of general fund spending in favor of trust funds. ${ }^{12}$ On the first tier, benefits of trust funds can be specifically identified and directly tied to revenues raised, whereas general fund expenditures are more diffuse. The greater the ability to identify the direct beneficiaries of trust fund increases makes trust fund taxes less politically painful to raise.

The second tier, according to Cogan, relates to the legislative committees with jurisdiction over tax-writing. The taxwriting committees have jurisdiction over the financing and spending of the largest trust funds. Other spending committees of Congress, by contrast, control the smaller trust funds and the general revenue of the federal government. When taxes need to be raised, the tax-writing committees naturally tend to favor the taxes and spending under their control. ${ }^{43}$

With respect to the perspective of average citizens, earmarking clearly has changed the way the public thinks about how government should be financed. This, in turn, has placed programs not funded through earmarks at a disadvantage. As budget scholar Allen Schick describes:

[E]armarking...is transforming American citizens into shoppers. Whereas a citizen pays taxes in support of government, a shopper pays only for the things he or she buys. As earmarks become more prominent, they make the federal government into a sort of 'boutique' in which Americans choose from the array of programs and pay for the ones they select. The boutique is relatively well stocked in programs financed by earmarked revenue, but the supply of items paid out of general fund revenues is sparse. One of the "goods" in the boutique is "the federal government." The huge general fund deficit tells us that Americans are not willing to pay the full cost of this item. ${ }^{44}$

According to Schick, earmarking encourages legislators to finance non-trust fund, or general fund, programs through deficits because no consensus exists among the public for individual general fund programs. Earmarking, as a result, acts as a road block impeding deficit and debt reduction. ${ }^{\text {is }}$ In addition, earmarking hampers the establishment of priorities during the budget process because existing spending is "locked in."

\section{Budgeting v. Trust Fund Budgeting}

One process problem with trust funds is a disharmony between good budgeting and the use of trust funds. Noted author Aaron Wildavsky describes the meaning of a budget as a document which contains "words and figures that propose expenditures for certain objects and purposes."

Furthermore, budgets link financial resources and human behavior "to accomplish policy objectives." "Wildavsky holds that since funding for a budget is usually limited, the budget becomes a "mechanism for making choices among alternative expenditures.",

\section{One process problem with trust funds is a disharmony between good budgeting and the use of trust funds.}

If budgeting involves making choices with limited funds, then, by extension, a budget must also involve an element of prioritization of program and budget item funding. The very concept of a budget implies that a ceiling, or a spending limitation, requires the government to live within a defined means. ${ }^{49}$ Prioritization seems inevitable if funding is indeed limited and budgets as a whole attempt to fund many different programs.

Prioritization is a distinct characteristic of federal budgeting. Among the numerous and diverse areas to which the federal budget devotes resources are national defense, the arts, commerce and trade, education, and health care. And, as evidenced by the large federal budget deficit, funds available to legislators are certainly limited.

Trust funds act as an encumbrance to the rational prioritization of program funding and thus have an adverse affect on the process of budgeting. Prioritizing program funding in a rational manner during each budget cycle allows legislators to easily direct any amount of available resources to any desired purpose in a given budget year. Simply put, rational action can be accomplished when legislators have a full range of funding options at their disposal. ${ }^{50}$

Trust funds clearly inhibit the rational prioritization of federal dollars using this definition. In each budget year, resources are automatically dedicated to the trust fund accounts and spending is targeted only to defined pro- 


\begin{tabular}{|c|c|c|c|}
\hline \multicolumn{4}{|c|}{$\begin{array}{c}\text { Table } 3 \\
\text { INCOME AND OUTGO } \\
\text { CREDIT TO TRUST FUNDS } \\
\text { FY 1995 } \\
\text { (dollars, in billions) }\end{array}$} \\
\hline Trust loind & rome & totaloog & Difference \\
\hline Social Security (OASDI) & 398.5 & 338.1 & 60.4 \\
\hline Federal Employee Retirement & 66.8 & 38.9 & 27.9 \\
\hline Medicare Part A & 114.8 & 114.9 & -0.1 \\
\hline Millitary Retirement & 34.6 & 27.8 & 6.8 \\
\hline Unemployment & 32.8 & 25.3 & 7.5 \\
\hline Highway & 23.9 & 22.7 & 1.2 \\
\hline Railroad Retirement & 12.4 & 11.2 & 1.2 \\
\hline Medicare Part B & 58.2 & 65.2 & -7.0 \\
\hline Veterans Life Insurance & 2.1 & 2.0 & 0.1 \\
\hline Airport and Airway & 6.4 & 7.4 & -1.0 \\
\hline Federal Employee Health & 16.2 & 15.9 & 0.3 \\
\hline Foreign Military Soles & 12.5 & 13.4 & -0.9 \\
\hline Other & 11.3 & 8.5 & 2.8 \\
\hline TOTAL & 790.5 & 691.3 & 99.2 \\
\hline $\begin{array}{l}\text { Source of figures: } \mathrm{OM} \\
\text { President, Analytical }\end{array}$ & FY 199 & 7 Budget Requ & st of the \\
\hline
\end{tabular}

interest. As will be discussed later, Congress must resolve these and other questions related to interest payments. If interest payments truly represent future benefits to be paid, the size of interest payments is an unacceptable burden on future taxpayers.

The distorting effect on the annual trust fund balances today is equally problematic. Trust funds depend on interest and other government transfers for surpluses, which belies a popular notion that the funds are self-supporting. ${ }^{55}$ A comparison of Tables 3 and 4 provides insight into this situation. Table 3 shows the aggregate income and outgo of the largest trust funds in FY 1995, which include interest and other government transfers. ${ }^{56}$ Under this construction, most of the trust funds have, or are close to having, positive annual balances, meaning more funds are placed into the trust funds than funds are drawn out of them.

Table 4 shows actual receipts and payments to the public

\begin{tabular}{|c|c|c|c|}
\hline \multicolumn{4}{|c|}{$\begin{array}{c}\text { Table } 4 \\
\text { RECEIPTS AND PAYMENTS TO THE } \\
\text { PUBLIC FOR TRUST FUND PROGRAMS } \\
\text { FY } 1995 \\
\text { (dollats, in billions) }\end{array}$} \\
\hline liust fond & \multicolumn{2}{|c|}{ Total Recejps Totdipaymenis } & \multirow{2}{*}{$\begin{array}{l}\text { opferente } \\
17.5\end{array}$} \\
\hline Social Security (OASDI) & 351.1 & 333.6 & \\
\hline Federal Employee Retirement & 4.5 & 38.9 & $-34,4$ \\
\hline Medicare Part A & 96.0 & 114.9 & .18 .9 \\
\hline Military Retirement & 0.0 & 27.8 & -27.8 \\
\hline Unemployment & 28.9 & 25.3 & 3.6 \\
\hline Highway & 22.6 & 22.7 & -0.1 \\
\hline Railroad Refirement & 3.9 & 7.9 & -4.0 \\
\hline Medicare Part B & 0.0 & 65.2 & -65.2 \\
\hline Veterans Life Insurance & 0.0 & 2.0 & -2.0 \\
\hline Airport and Airway & 5.5 & 7.4 & -1.9 \\
\hline Federal Employee Healith & 0.0 & 15.9 & -15.9 \\
\hline Foreign Military Soles & 0.0 & 13.4 & -13.4 \\
\hline Other & 4.4 & 8.0 & -3.6 \\
\hline TOTAL & 516.9 & 683.0 & 166.1 \\
\hline $\begin{array}{l}\text { Source of figures: } \mathrm{OM} \\
\text { President, Analytical }\end{array}$ & $\begin{array}{l}\text { FY } 19 \\
\text { spectic }\end{array}$ & et Req & st of the \\
\hline
\end{tabular}

in FY 1995, which has the effect of excluding governmental transfers. All of the major trust funds, with the exception of the Social Security and unemployment, now have a negative balance. One of the largest changes is in the federal retirement trust fund, which went from a $\$ 28$ billion positive balance to a negative $\$ 34$ billion balance between Tables 3 and 4. Although a large part of the explanation for the change is governmental accounting transfers other than interest, interest clearly plays a significant role. ${ }^{57}$ The federal retirement trust funds earned almost $\$ 29$ billion in interest in FY 1995.

One disturbing aspect of the interest transfer system occurs in the Medicare Part B trust fund. The Part B program pays for some medical services to Medicare beneficiaries that are not covered by Medicare Part A. The general fund of the budget currently funds 70 percent of the cost of Part B coverage, with beneficiaries paying the remaining cost 
through deductions from Social Security beneficiary payments. Despite a 70 percent subsidy from the general fund, the Part B trust fund was still credited with $\$ 1.9$ billion of interest in FY 1995.

Payments of interest to the trust funds, not unlike payments of interest in any situation, are predicated on the assumption that contributing taxpayers must be compensated for the time value of money. In part, the payment of interest is appropriate because the funds, if invested in the private sector, would generate a certain level of positive return. ${ }^{58}$ This line of thinking assumes that federal trust funds are very much like private investment vehicles, such as private trusts, and should be treated the same with respect to payments of interest. However, federal and private trust funds are not the same. Contrary to popular thought, federal trust funds are not savings held in trust for taxpayers but are just taxes paid by current workers to be used only to pay current benefits and accumulate paper surpluses. ${ }^{59}$ As the Congressional Budget Office has held:

[T]he trust fund label itself is arguably broad and misleading. The label fuels the notion that these federal programs are like private trust funds - a pool of assets managed for the exclusive benefit of recipients and whose terms and conditions cannot be changed without serious legal consequences. No large trust fund meets this description.... ${ }^{60}$

\section{[P]rivatizing Social Security funds is problematic in many respects.}

Karl Borden, professor of financial economics at the University of Nebraska, argues that while the value of private-sector securities is based on the market's perception of the ability of that asset to produce future wealth, no "real" assets underlie the value of federal securities, which are the sole investments of trust funds. ${ }^{\text {61 }}$ Government securities merely represent a claim based on the government's ability to tax wealth created at some later time. ${ }^{62}$ In a recent editorial, The Washington Post commented that the idea that Social Security works like a giant savings account is akin to "mythology" and argued that the system works less like a savings plan than an income transfer between generations. ${ }^{63}$

The current debate over partially privatizing Social Security Trust Fund investments provides an illustration of the difficulty in considering private and federal trust fund amounts the same. Private investment of Social Security Trust Fund contributions has been offered recently as a way to increase the potential return to beneficiaries, ensure the
Social Security system will not succumb to political pressures, and reduce interest costs to the federal government. However, privatizing Social Security funds is problematic in many respects.

Among critics of recent privatization proposals is the Congressional Budget Office $(\mathrm{CBO}){ }^{64}$ One concern raised by CBO in a 1993 report was risk - should future beneficiaries or the federal government be permitted to place Social Security revenues in private investments, most of which would include an element of risk? Another concern under privatization, was that, some private investments obtaining Social Security funds would be favored over others. The underlying concern of $\mathrm{CBO}$ is whether the federal government should be in the business of picking private investment winners and losers.

Still a third concern raised by $\mathrm{CBO}$ is the potential loss of equity between beneficiaries. As former $\mathrm{CBO}$ Director Robert Reischauer explained with respect to beneficiary investment of Social Security contributions:

Benefits under the Social Security system are determined by a complex system that seeks a balance between equity and ensuring an adequate level of benefits to the poorest recipients. Moving to [a system where individuals make their own investments]' would alter this balance. The amount of retirement income derived from funds... would be determined by the amount invested and the rate of return on that investment. That payout scheme would be equivalent to moving to a defined contribution plan, instead of a defined benefit plan. ${ }^{65}$

Under this scenario, savvy investors could earn higher returns and higher benefits than under the current system. Those who are not as capable could actually end up losing large portions of future benefits.

The current debate over privatizing Social Security Trust Fund investments illustrates that federal trust funds are fundamentally different from private trust funds, and therefore should not be treated as an equal with respect to interest consideration. Whether such transfers are appropriate in the first place is as important as whether the federal government can afford massive interest transfers in an era of tight budgets. For a few trust funds, such transfers may be entirely appropriate. For others, interest transfers should be reduced or eliminated for lack of a good policy rationale.

\section{The Inadequacy of Budget Reconciliation}

The final process problem with trust funds relates to the inability of the budget reconciliation process to respond 
adequately to entitlement and, therefore, trust fund growth. In response to the first process problem described, which said that trust funds inhibit the rational prioritization of fecteral spending, one could counter that budget reconciliation adequately addresses this problem. Budget reconciliation is the part of the budget process which enables Congress to review the underlying structure of entitlements, including trust fund programs, during each budget cycle. The budget process permits Congress to undertake the budget reconciliation process every year if so desired. Budget reconciliation is the single mechanism which can help Congress maximize rationality in the budget process. ${ }^{60}$

At times, budget reconciliation has worked quite well in terms of facilitating large budget savings. In 1981, in the second year of use, budget reconciliation provided cuts of $\$ 130$ billion in outlays over a three-year period, according to estimates at the time. ${ }^{67}$ Most recently, two significant budget reconciliation laws were enacted: in 1990, when outlay cuts were estimated to total $\$ 323$ billion over five years and in 1993, with cuts of $\$ 255$ billion.

The effectiveness of the budget reconciliation process is limited, however, because of serious shortcomings and built-in weaknesses. Allen Schick outlined these adeptly:

[Reconciliation] is not an inherently potent process. At all stages, reconciliation depends on the willingness of key congressional participants to make it work....Although the Budget Act directs committees to respond to reconciliation instructions, it provides no effective sanctions if they fail to do so. The instructions do not dictate which programs are to be cut or how savings are to be measured. If committees concoct false or unrealistic savings, the budget committee cannot unilaterally substitute more appropriate cutbacks. They can ask the House or Senate to approve alternative savings, but the floor is not a hospitable place for sorting out conflicts among committees or for making hard choices. Even when legitimate savings have been recommended, there is no assurance that they will materialize. The Budget Act does not require that Congress enact a reconciliation bill. It only provides that Congress, when instructed by a budget resolution, prepare and consider such a measure. ${ }^{68}$

The shortcomings of budget reconciliation have contributed to the budget deficit remaining stubbornly high and trust fund entitlement growth continuing to rise. Since 1985, despite enactment of major budget reconciliation Jaws in 1990 and 1993, the budget deficit has not fallen below $\$ 149$ billion, and mandatory programs have grown in their share of the federal budget from 56 percent to 64 percent. Of the $\$ 323$ billion of spending cuts enacted through budget reconciliation in 1990 and $\$ 255$ billion of cuts enacted in 1993, only $\$ 75$ and $\$ 88$ billion in savings were sought from entitlement programs in these years, respectively.

The sbortcomings of budget
reconciliation bave contributed to the
budget deficit remaining stubbornly
bigh and trust fund entitlement growth
continuing to rise.

Indeed, budget reconciliation has done little to constrain the rapid growth of entitlement programs. Medicare is one example, growing from a $\$ 31$ billion program in FY 1980 to a $\$ 142$ billion program in FY 1994 . Over the same period, the positive balance of the Medicare Trust Fund grew from $\$ 14.5$ to $\$ 129.5$ billion.

According to Schick, Medicare has been "an especially fertile area for inventive budgeting." Questionable methods of budgeting for Medicare have included extending so-called "temporary" measures two or three times and using special rules of the budget baseline to report a spending increase as a cutback. ${ }^{69} \mathrm{Few}$ actions have been taken during budget reconciliation that would make fundamental changes to the program to achieve large budgetary savings, such as reducing the types of medical services covered and/or reducing numbers of beneficiaries who qualify. In fact, budget reconciliation has often provided a good vehicle for Medicare program expansions by Congress. ${ }^{70}$

Arguably, inventive budgeting for Medicare continues in the current Congress. In 1995, the Republican majority passed Medicare reform proposals within budget reconciliation legislation. Among the more significant proposals to achieve Medicare savings are the "voluntary" moving of Medicare beneficiaries into managed health care programs, and a so-called "fail safe" mechanism, which simply meant that if enough savings in Medicare were not attained by the reforms collectively, the program would be cut automatically at some point in the future. Again, no direct cuts in medical services were offered. Even under Republican Medicare reform proposals, Medicare spending is still projected to grow from $\$ 4,816$ to $\$ 6,734$ per beneficiary by the year $2002,{ }^{71}$

Although budget reconciliation does not have a direct causal link to the growth of trust funds, this essential bud- 
get mechanism clearly has not been utilized to make wholesale changes in entitlement programs to help constrain program and trust fund growth. In this respect, budget reconciliation represents a trust fund process problem. Budget reconciliation is the only mechanism within the budget cycle that can address the relationship of trust funds to the federal budget, yet the process has limited effectiveness because of inherent weaknesses.

Proponents of trust funds would argue that less tinkering with trust fund programs in reconciliation is the best way to preserve program continuity, and fewer changes during the process means programs are not being altered merely for budgetary reasons. Indeed, budget considerations dominate budget reconciliation, which at least partially explains the reluctance of members of Congressional authorizing committees to make budget reconciliation work effectively.

\section{Options for Change}

Trust funds are a problem because they limit budgetary flexibility and control. Budgetary flexibility and control are affected because trust funds inhibit rational budgetary processes, require interest transfers which distort the condition of the trust funds and may place undue burdens on future taxpayers, create a public perception that they are something more than mere budgetary accounts, and facilitate the compartmentalization of spending through earmarking. In addition, trust fund programs are not easily controlled through budget reconciliation, the primary budget process by which to exert control over trust fund programs.

What can Congress do to address these issues? Any change would be difficult to accomplish given the political nature of the trust funds. Trust funds exist primarily to help protect spending for certain federal programs. Any possible change would have to overcome the strength of this political benefit. That said, the following are some possible options for change.

Create no new trust funds. Given the issues discussed, the fundamental first step is that at the very least, Congress should avoid establishing any additional trust funds. In the current Congress, many proposals exist to establish new trust funds. Proposals include establishing trust funds for national health insurance; affordable housing; displaced defense workers, research and development; and, oddly, boxer safety, retirement, and retraining. ${ }^{72}$ If Congress is to prevent further compartmentalization of the federal budget, no new trust funds should be established no matter how worthy the purpose.
Eliminate trust funds. Congress should consider the appropriateness of eliminating some, if not all, trust funds. Given political considerations, eliminating any trust funds would be extremely difficult to achieve. However, this reality should not detract those who desire a more effective budgetary regime for the future. A blueprint for action might encompass eliminating all but the largest trust funds in omnibus legislation, thus narrowing the debate over trust funds as a budget mechanism to the appropriateness and desirability of each of the largest trust funds.

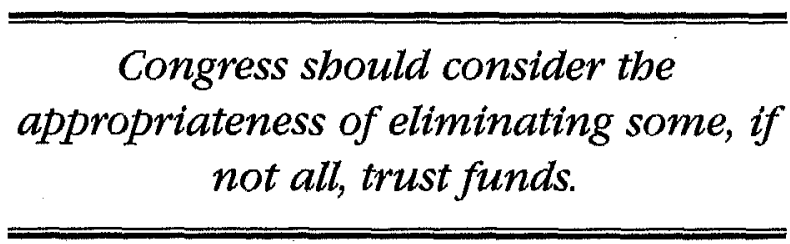

Some trust funds would be appropriate to keep from a policy standpoint. For example, trust funds for civil servants and military retirees maintain a relationship which exists in the private sector with respect to employee retirement benefits. The federal government should do as much as possible to maintain employee/employer relationships similar to the private sector.

On the other hand, a good policy rationale for maintaining other trust funds does not exist. At a minimum, a trust fund might be "justified" if fully-financed by dedicated revenues. The Medicare Part B trust fund, however, is a trust fund which receives a majority of funding from the general fund of the budget through interfund transfers and therefore is not a self-financed entity. This trust fund should be eliminated. Similarly, a good policy rationale might not exist for maintaining Social Security or the transportation trust funds, aside from obvious political considerations. If necessary, these programs and their dedicated revenues can be adequately accounted for in separate funds within the budget without a "trust fund" designation. Another option would be to finance programs on a pay-as-you-go basis, reducing the need for trust funds

Modify the treatment of trust fund interest. In the probable absence of an elimination of federal trust funds, crediting of trust fund interest should be reformed.

The largest federal trust funds currently earn interest which is pegged to a given market rate. For example, securities posted to the Social Security, Medicare, Civil Service Retirement, and Railroad Retirement trust funds are pegged to the average market yield on medium- and long-term Treasury securities. ${ }^{73}$ Given the inherent differences between federal and private trust funds, however, as well as the special nature of the securities posted to trust fund 
accounts, one must question whether some, or any, of these funds should receive a rate of interest which is close to a private market rate.

A comprehensive reevaluation of interest transfers should be undertaken. The reevaluation should focus on both the rate of interest paid and the appropriateness of providing interest credits in the first place. For some trust funds, such as the civil service and military retirement trust funds, the federal government should continue to credit a market rate of interest. Private sector employees receive the benefit of market rates of interest for earnings on pension funds and public employees should receive the same as long as these pension funds exist.

The Social Security Trust Fund should receive a reduced rate of interest, such as one compensating only for inflation. Future taxpayers are already going to have tremendous tax burdens placed upon them to pay for future benefits even without that portion of benefits represented by current interest payments to the trust fund. Of more immediate concern, the high level of interest earned by the Social Security Trust Fund skews the trust fund balance, reducing in turn the perceived urgency to reform the substantive aspects of the Social Security program.

Some trust funds should receive no interest at all, such as some transportation trust funds. As described earlier, federal transportation excise taxes are more public in nature since the taxes are not assessed for the benefit of some specific group of taxpayers to provide a defined future benefit (e.g., working Americans and Social Security payroll taxes providing Social Security benefits). Instead, the taxes levied are presumed to represent taxes assessed for general public purposes, such as airport infrastructure and interstate highways.

Accounts of programs serving public purposes should not be credited with interest. ${ }^{74}$ In a sense, the practice is a method to secure greater funding for a purpose through "the back door"; that is, after assessing excise taxes for public purposes, additional funding is secured by assessing interest costs on the public instead of by direct levy. One could argue that the special nature of excise taxes warrants separate accounts and interest consideration. However, excise and income taxes are levied on the public for public purposes and should be treated the same.

A second option for helping to deal with trust fund problems associated with interest would be to explicitly depict the cost of interest credited to the trust funds in the annual federal budget. Such a proposal was made by former Senate Budget Committee Chairman Jim Sasser (D-TN) in
$1990 .{ }^{75}$ The "Gross Interest Legislation Act" would have required the establishment of a functional category for gross interest on the public debt. Currently, the budget depicts only net interest, which factors out interest credited to the trust funds. The purpose of depicting gross interest, according to the bill, was to have the budget "focus greater attention on the consequences of borrowing from the trust funds to finance current spending needs. ${ }^{.76}$ Presumably, such a measure would also serve the important purpose of focusing more attention on the amounts of interest flowing into the trust funds. This legislation was not enacted.

\section{Make trust fund programs more responsive to the} budget process. Offsetting the negative effects of the trust funds on budgeting requires that entitlement programs financed by the trust funds are less immune to the demands arising in the budget process, including spending control and prioritization. The most prominent proposal discussed in this light is to place hard spending "caps" on entitlement programs, many of which have trust funds. If a spending cap in a given budget year is breached, Congress and the President would be forced to take actions to reduce spending in each entitlement area. Under such a scenario, budget reconciliation would likely be triggered, which as described earlier is currently initiated only if Congress voluntarily seeks budget savings. ${ }^{7}$

The fecleral government has already taken a small step in this direction. In 1993, President Clinton signed Executive Order 12857 which required oversight of entitlement spending for FY 1994-1997 and the recommendation of legislative actions to the Congress if projected spending levels are exceeded. However, the enacted spending "caps" agreed to were flexible and could be adjusted for a number of reasons, including unexpected increases in the beneficiary population. In addition, the process does not require budget reconciliation to be initiated, meaning that Congress is not forced to make entitlement spending cuts.

\section{Conclusion}

To improve the budgeting and the condition of the fecleral budget, Congress must address problems associated with trust fund use. The best course of action would be to begin to eliminate many, if not most, trust funds.

Eliminating trust funds would make the budgeting process easier and more effective.

Perhaps what is most important is that Congress and the President begin a dialogue about this issue soon. Many serious federal budget issues need to be addressed. The best way to address budget problems is through maximum 
budgetary flexibility and control for Congress and the President. Trust fund reform will certainly help in this respect, and should therefore be a part of any budgetary reform agenda.

As we reform the federal budget, we must keep an eye on the future. Anti-tax backlash and the desire of the public to have more control over federal government spending of tax dollars could result in additional trust funds if we do nothing to change course. Reforming trust fund budgeting now will help avoid the further proliferation of trust funds and lessen constraints on the budget. $\star$

\section{Notes}

II would like to thank my article editor, Robert Zahradnik, and associate editor; Charisse Snith, for their time and tremendous help in putting together this article. I also greatly appreciate the excellent suggestions of Professor Bernard Pitsvada of The George Washington University and Professor David Sitrin of Georgetown University. Many thanks also to Heather Johnston, Stephen Liftman, and Professor Jill Kasle for their efforts and encouragement. Finally, I would like to thank my wife, Cassandra, for her patience and understanding.

'Office of Management and Budget, FY 1996 Budget Request of the Presiclent (Washington, D.C.: Government Printing Office, 1995), 251.

${ }^{2}$ Ibicl., 255.

${ }^{3} I$ Ibid., 251.

'U.S. Congressional Research Service, David Koitz; Gene Falk; and Philip Winters; "Trust Funds and the Federal Deficit," 90106 EPW, 26 February 1990, 5.

sIbid.

${ }^{6}$ Congressional Budget Office, Federal Debt and Interest Costs (Washington, D.C.; Government Printing Office, May 1993), 28.

${ }^{7}$ Statistics within this article are derived from the FY 1996 \& FY 1997 budget submissions of President Clinton (Washington, D.C.: GPO, 1995 \& 1996), unless noted otherwise.

${ }^{4}$ Congressional Record, 66th Cong., 1st sess., 29 April 1920, H6285.

"The Tax Foundation, Inc., Federal Trust Funds, Budgetary and Other Implications, Washington, D.C., 1970, 7.

${ }^{10}$ House Committee on Ways and Means, The Social Security Act of 1935, 74th Cong., 2nd sess., 1935. H. Rept. 74-615, 1415.

"See House Committee on Ways and Means: Hearings on Social Secutrity, 76th Cong., 1st sess., 1939. More specifically, one should review the testimony of Dr. Abraham Epstein on 27 February 1939.

${ }^{12}$ House Committee on Ways and Means, The Social Security Act of 1935, 15,

${ }^{13}$ Ihid.
${ }^{16} T$ The old-age reserve account was part of the general fund portion of the budget, at that time referred to as the "administrative budget."

${ }^{15}$ Senate Committee on Finance, The Social Security Act Amendments of 1939, 76th Cong., 2nd sess., 1939; S. Rept. 76$728,15$.

${ }^{16}$ See House Committee on Ways and Means: Hearings on Social Securrily, 76th Cong., 1st Sess., 1 February 1939, 41.

${ }^{17}$ Ibid.

${ }^{18}$ Ibid., 16.

${ }^{10}$ Senate Committee on Finance, 15.

"the Tax Foundation, 11.

${ }^{21}$ Ibid., 12.

${ }^{22}$ U.S. Congressional Research Service, "Social Security, Medicare, and the Unified Budget," S. Print No. 83, 99th Congress, 1st Session, 5.

${ }^{23}$ Budgetary "presentation" concerns the manner in which figures are presented in budget documents.

${ }^{24}$ Naomi Sweeny, "Major Criticisms of the Federal Budget," Bureau of the Budget, Staff Papers and Other Materials Reviewed by the President's Commission, President's Commission on Budget Concepts (Washington, D.C.: Government Printing Office, 1967), 19.

${ }^{25}$ Report of the President's Commission on Budget Concepts (Washington, D.C.: Government Printing Office, 1967), $14 \&$ 25-28.

${ }^{26} U$.S. Congressional Research Service, 5.

${ }^{27}$ Report of the President's Commission on Budget Concepts, 26.

${ }^{24}$ Ibid., 27.

${ }^{20}$ This is clearly the case of the Social Security Trust Fund.

${ }^{30}$ In "The Budget Dilemma; Searching For A New Consensus," Harry Havens (1988, The GAO Journal, 28) discusses the fact that it is not the legal status of a trust fund which protects beneficiaries, it is the political commitment underlying it. Thus, establishing an account as a "trust fund" helps to solidify political commitment around a program.

${ }^{31}$ Office of Management and Budget, Statement of Federal Accountancy Concepts, Number 2, Executive Office of the President (Washington, D.C.: Government Printing Office, 
1995), 6. A fiduciary is a person who holds or controls property for the benefit of another person. It includes anyone who has discretionary authority or control with regard to a fund's assets. (U.S. Congressional Research Service, "Private Pension Plan Standards: A Summary of ERISA," 94-506EPW, 3 March 1995, 4.)

${ }^{32}$ U.S. Congressional Research Service. "Private Pension Plan Standards: A Summary of ERISA," 95-506EPW, 3 March 1995, 17.

${ }^{33}$ Office of Management and Budget, 1995, 6.

${ }^{3}$ The Random House Dictionary of the English Language, Second Edition, 1987.

${ }^{35}$ "Drawing down" means reducing the surplus balance of the trust fund.

${ }^{36}$ Congressional Record, 104th Cong., 1st sess., 1 August 1995, H8143.

${ }^{37}$ Congressional Record, 104th Cong, 1st sess., 12 May 1995 , H4904.

${ }^{38}$ U.S. General Accounting Office. Earmarking in the Federal Government, GAO/AIMD-95-216FS, 1995, 2.

${ }^{30}$ Allen Schick, The Capacity to Budget (Washington, D.C.: The Urban Institute Press, 1990), 150.

"See James M. Buchanon, "Public Finance and Public Choice," National Tax Journal, 28 December 1975, 383-94, as published in: Catherine Elliot and Sam Baker, Readings in Public Sector Economics, (D.C. Heath and Co., 1990).

${ }^{41}$ Ibid., 51.

"John F. Cogan, The Budget Puzzle: Understanding Federal Spending (Stanford, CA: Stanford University Press, 1994), 39.

${ }^{43}$ Ibid.

"Schick, 151-152.

${ }^{45}$ This is a concept extracted from "The Budget Dilemma: Searching for a New Consensus" (The GAO Journal, Winter 1988/89, 13-15) where Harry Havens describes how trust funds act as a structural rigidity impeding deficit and debt reduction.

${ }^{46}$ American Association of Retired Persons, The AARP Public Policy Agenda, Washington, D.C., 1995, 20.

${ }^{17}$ Aaron Wildavsky, The New Politics of the Budgetary Process, 2nd Edition (HarperCollins Publishers, 1992), 2.

${ }^{48}$ Ibid.

${ }^{49}$ Jay M. Shafritz, The Dorsey Dictionary of American Government and Politics (The Dorsey Press, 1988), 69.

${ }^{50} \mathrm{I}$ have extracted the concept of a "rational prioritization" of federal spending from concepts embodied in the "rational model" of public budgeting. The rational model promotes the view that rationality is promoted in the federal budget when all available spending options are considered and the best option is chosen. A 'best option' is detemined to a large degree by sophisticated quantitative techniques (see Don Cozetto, Mary Grisez Kweit \& Robert Kweit, Public Budgeting: Politics, Iristitutions, and Processes, [Longman Publishers, 1995], 188). For my purposes, I simply seek a more rational process within the spirit of the rational model which may or may not lead to an optimal decision that could be reached using traditional rational model methods.

${ }^{51}$ Donald Axelrod, Budgeting For Modern Government (St. Martin Press, 1995), 251.

${ }^{52}$ It is important to note that if the fecieral government were running a surplus, not a budget deficit, the trust funds would still earn interest on these security postings.

${ }^{53} \mathrm{By}$ means of comparison to this interest payment to social security, the federal government spent less on areas funded primarily by the general fund portion of the budged including non-defense science and technology ( $\$ 17$ billion), housing assistance ( $\$ 27$ billion), and education for the disadvantaged ( $\$ 7$ billion).

${ }^{5.1}$ There is evidence that this is occurring now. In the Intermodal Surface Transportation Efficiency Act (ISTEA) of 1992, Congress purposely began to "spend down" the highway trust fund surpluses which include past interest payments.

${ }^{55}$ U.S. Congressional Budget Office, 31.

"5\%"Outgo" means any outflow of money from trust fund accounts.

"Other types of "interfund" transfers include federal contributions to employee retirement, health care, and other benefits, as well as direct contributions of the general fund to trust fund programs.

${ }^{5 k}$ Thus, for example, if a future Social Security beneficiary could invest his or her current Social Security taxes in the private sector, he or she could expect to earn a rate of return based on risk or prevailing interest rates, and therefore maintain and possibly increase the value of their investment over tine.

${ }^{51}$ Michael Rosenberg. "Discussion Central: Social Security Information," http://www.disccent.com/socsec/info.html\# TrustFunds, 2 .

${ }^{(1)}$ U.S. Congressional Budget Office, 28.

"See Karl Borden, Dismantling The Pyramid: The Why and How of Privatizing Social Security, the CATO Institute Project On Social Security Privatization, Washington, D.C., 14 August 1995.

${ }^{62} I$ Ibid., 3. In explaining the difference, Professor Borden states that real assets may be either tangible or intangible but they are always real. The claim on those assets may be direct or indirect, but the value of security is grounded in the market's perception of the ability of that asset to produce future wealth. The value of security exists in the present as an expression of the future cash flows the asset is capable of prodicing. Citizens who own private securities are holding a piece of the nation's wealth that currently exists; it is wealth 
that they, as current participants in the nation's economy, helped to create. In theory, and in some cases reality, if the firm issuing the security is liquidated, the holder of the security may claim the real assets and realize their value as they are sold and redistributed. Government securities are fundamentally different. No real assets underlie their value.

${ }^{63}$ Editorial, The Wasbington Post, 27 February 1995, A19.

${ }^{64}$ U.S. Congressional Budget Office, 34 .

${ }^{6}$ Robert Reischauer, Testimony before the House Subcommittee on Social Security of the Committee on Ways and Means: Hearings on Proposals for Alternative Investment Of The Social Security Trust Fund Reserves, 103rd Cong., 2nd sess., 4 October 1994, Serial 103-106, 29. A defined benefit plan is a plan which specifies the benefits or method of determining the benefits, but not the contribution; a defined contribution plan is on in which contributions are fixed, but not the benefits.

${ }^{64}$ Budget reconciliation works as follows. The initial budget document of each budget cycle, the budget resolution, takes one of two budgetary paths; either providing simple budget allocations for appropriated, or discretionary programs, or, in addition, including instructions for budgetary savings from specific authorizing committees which have jurisdiction over entitlement programs. In choosing the second path, budget reconciliation is initialized. Authorizing committees are then charged with changing entitlement laws within the budget reconciliation document to achieve specified savings within the budget resolution.

${ }^{67}$ Schick, 91.

\section{Bibliography}

Axelrod, Donald. Budgeting for Modern Government. St. Martin Press, 1995.

Baker, Sam and Catherine Elliot. Readings in Public Sector Economics. D.C. Heath and Co., 1990.

Borden, Karl. Dismantling The Pyramid: The Why and How of Privatizing Social Security, the CATO Institute Project On Social Security Privatization, Washington, D.C., 14 August 1995.

Cogan, John F. The Budget Puzzle: Understanding Federal Spending. Stanford: Stanford University Press, 1994.

Cozzetto, Don, Mary Grisez Kweit, and Robert Kweit. Public Budgeting: Politics, Institutions, and Processes, Longman Publishers, 1995.

Havens, Harry. "The Budget Dilemma: Searching For A New Consensus." The GAO Journal, 1988.

House Subcommittee on Social Security of the Committee on Ways and Means, Hearing on Proposals for Alternative Invesiment of The Social Security Trust Fund Reserves, October 1994, Serial 103-106.

House Committee on Ways and Means, The Social Security Act
${ }^{68}$ Ibid., 114.

${ }^{60}$ Ibid., 116.

${ }^{70} \mathrm{Ibid}$.

${ }^{71}$ House Committee on Ways and Means, H,R. 2425: The Medicare Preservation Act of 1995, H. Rept. 104-276, Part I, 104th Congress, 1st Session, 115.

${ }^{72}$ The proposal establishing a tusst fund for boxer safety, retirement, and retraining is included in legislation introduced by Representative Major Owens (D-NY) (H.R. 1845, 104th Congress).

${ }^{73}$ U.S. Congressional Budget Office, 32.

${ }^{74}$ The federal government levies income taxes for other public purposes, yet does not credit interest, for example, to spending categories of general education or public housing.

${ }^{75}$ U.S. Senate Committee on the Budget, S. 3011: The Gross Interest Legislation Act, S. Rept. 101-438, 101st Congress, 2nd sess., 1990.

${ }^{76}$ Ibid., 4.

"It is important to note here that it is difficult to "force" Congress to do anything. If faced with such a situation, Congress could simply pass revisions to the law enabling it to avoid having to make spending cuts. Congress did this the recent period when the budget was covered by the supposedly strict spending limits of the Gramm-Rudman-Hollings deficit reduction law. of $1935,74^{\text {th }}$ Cong., $1^{\text {st }}$ sess, 1935 , H. Report 74-615.

Office of Management and Budget. Statement of Federal Accountancy Concepts, Number 2, Executive Office of the President, 6 June 1995.

Office of Management and Budget. FY 1996 Budget Request of the President, Analytical Perspectives, Washington, D.C.: Government Printing Office, 1995.

Office of Management and Budget. FY 1997 Budget Request of the President, Analytical Perspectives, Washington, D.C.: Government Printing Office, 1996.

Report of the President's Commission on Budget Concepts, Washington, D.C.: Government Printing Office, October 1967.

Rosenberg, Michael. "Discussion Central: Social Security Information." Website: http://www.disccent.com/socsec/ info, html\# TrustFunds.

Schick, Allen. The Capacity to Budget. Washington, D.C.: The Urban Institute Press, 1990.

Senate Committee on Finance, The Social Security Act Amendments of $1939,76^{\text {th }}$ Cong, $2^{\text {nd }}$ sess., S. Rept. 76-728.

U.S, Senate Committee on the Budget, S. 3011: The Gross 
Interest Legislation Act, S. Rept. 101-438, 101 Congress, $2^{\text {nd }}$ Session, 1990.

Shafritz, Jay M. The Dorsey Dictionary of American Government and Politics. The Dorsey Press, 1988.

Sweeny, Naomi R. Major Criticisms of the Federal Budget, Bureau of the Budget, Staff Papers and Other Materials Reviewed by the Presiclent's Commission on Budget Concepts. Washington, D.C.: Government Printing Office, October 1967.

The Tax Foundation, Inc. Federal Trust Funds, Budgetary and Other Implications. Washington, D.C., 1970.

U.S. Congressional Budget Office, "Federal Debt and Interest Costs", May 1993.

U.S. Congressional Research Service. Koitz, David, Gene Falk and Philip Winters. "Trust Funds and the Federal Deficit." 90-106EPW, 26 February 1990.

U.S. Congressional Research Service. "Social Security, Medicare, and the Unified Budlget." S. Print No. 83, 99" Congress, $1^{\text {st }}$ Session.
U.S. Congressional Research Service. Schmitt, Ray. "Prizate Pension Plan Standards: A Summary of ERISA", 95-506EPW, 3 March 1995.

U.S. General Accounting Office. Earmarking in the Federal Government, GAO/AIMD-95-216FS, 1995.

U.S. House Committee on Ways and Means, H.R, 2425: The Medicare Preservation Act of 1995, H. Rept. 104-276, Part I, $104^{\text {th }}$ Congress, $1^{\text {st }}$ Session, 1995.

U.S. House Committee on Ways and Means, Hearings on Social Security, $76^{\text {th }}$ Congress, $2^{\text {nd }}$ Session, 1939, Committee Print 18.

U.S. Senate Committee on the Budget, Social Security Preservation ACt, $101^{\text {st }}$ Congress, $2^{\text {ml }}$ Session, 1990, S. Report $101-426$.

Wildavsky, Aaron. The New Politics of the Budgetary Process. $2^{\text {nd }}$ Edition, Harper Collins Publishers, 1992.

1994 Advisory Council on Social Security, report of 10 \& 11 February 1995, meeting of the Advisory Council on Social Security, available from http://www.ssagov/policy/advisory_council_021095.html. 